\title{
Business Developments and Stabilization Policies
}

$\mathbf{E}$ CONOMIC activity in the first half of 1973 expanded at a very brisk pace in response to stimulative policy actions taken earlier. However, some economic measures, such as production and employment, rose at a less rapid pace in the second quarter of 1973 than in the first, partially reflecting capacity constraints. Prices increased sharply throughout the first six months of the year.

Rapid monetary growth in the first half of 1973 was accompanied by strong demands for credit and rising interest rates. The Federal budget was in deficit by about $\$ 9$ billion in the fiscal year just ended. Experience suggests that less expansionary stabilization actions will be required to achieve lasting success in curbing inflationary pressures, regardless of the workings of Phase IV controls.

\section{Business Developments}

Spending, production, employment, and income growth began to accelerate in mid-1971, after having risen at a moderate pace in the preceding several quarters, This expansion continued at rapid rates over the subsequent two-year period.

Spending - Total spending, the course of which is strongly affected by monetary and fiscal actions, increased at a 12.3 percent compounded annual rate of change in the first half of 1973. For comparison, total spending increased 10.6 percent in 1972 and 9.3 percent in 1971. Final sales (that is, total spending other than for changes in inventories) rose at a 13 percent rate in the first two quarters of 1973.

Production-.. Preliminary data indicate that real output growth slowed in the second quarter of 1973 to a 2.6 percent annual rate, after rising at an 8.6 percent rate in the first quarter and by 7 percent in 1972. For the first half of 1973 , real product increased at a 5.6 percent rate, considerably above its long-term average of 3.8 percent in the past fifteen years.
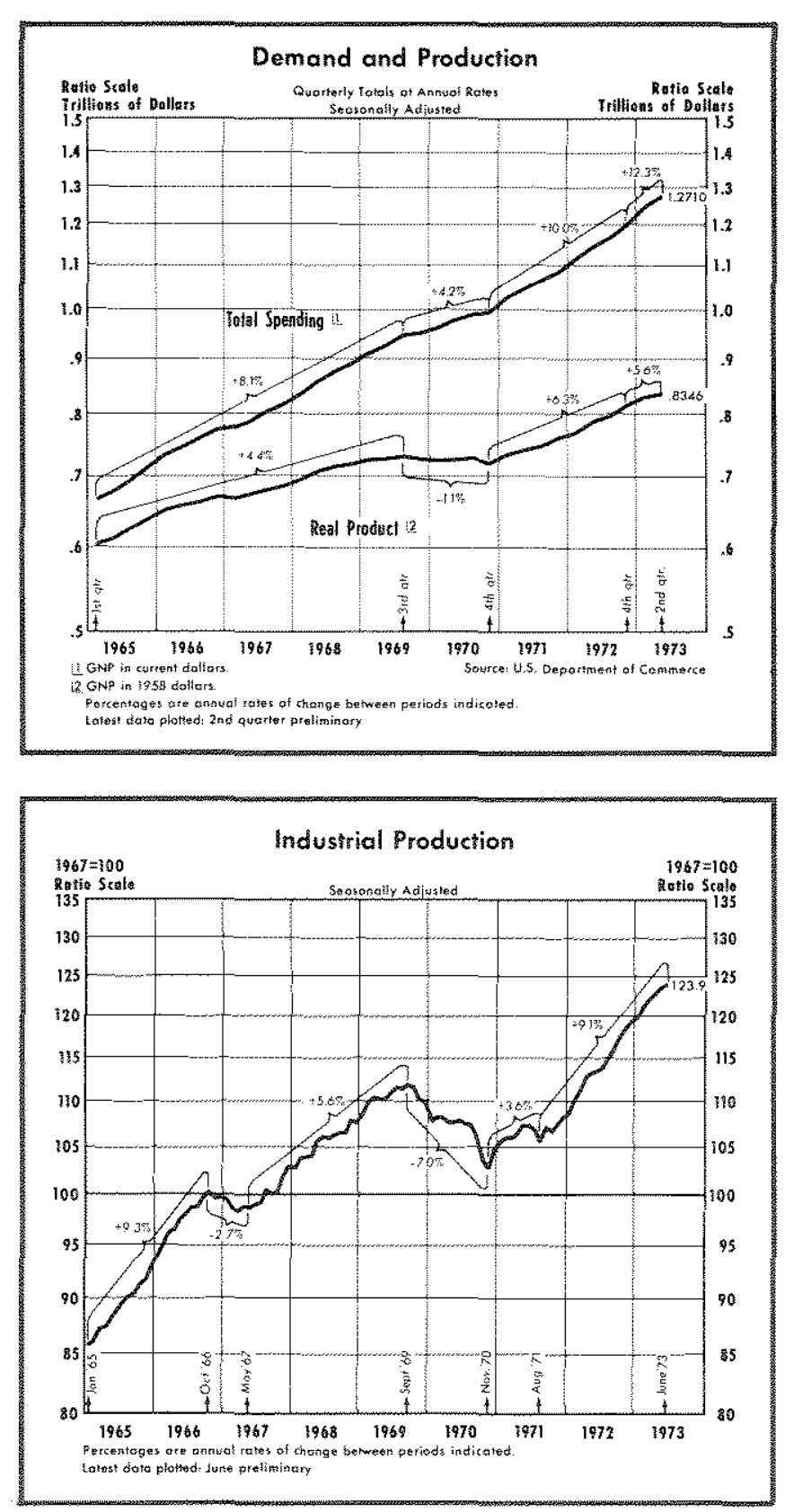

Page 3 
Industrial production, which increased at a 9.5 percent rate from August 1971 to the end of 1972, rose at a 9.7 percent rate in the first three months of 1973 and at a 6.4 percent rate in the second three months. Real output and industrial production growth for the first half of 1973 suggest that real economic activity has been slowing toward a more sustainable, longterm trend.

Employment - Total civilian employment has expanded at a relatively rapid 3.8 percent annual rate in the past seven months, compared with a trend rate of 1.6 percent from 1957 to 1972 . The unemployment rate of all civilian workers fell to 4.7 percent in July after holding steady at about 5 percent from January to May. From May 1971 to December 1972, total civilian employment rose at a 3.1 percent anmual rate, and the unemployment rate fell from 6 percent to 5.1 percent.

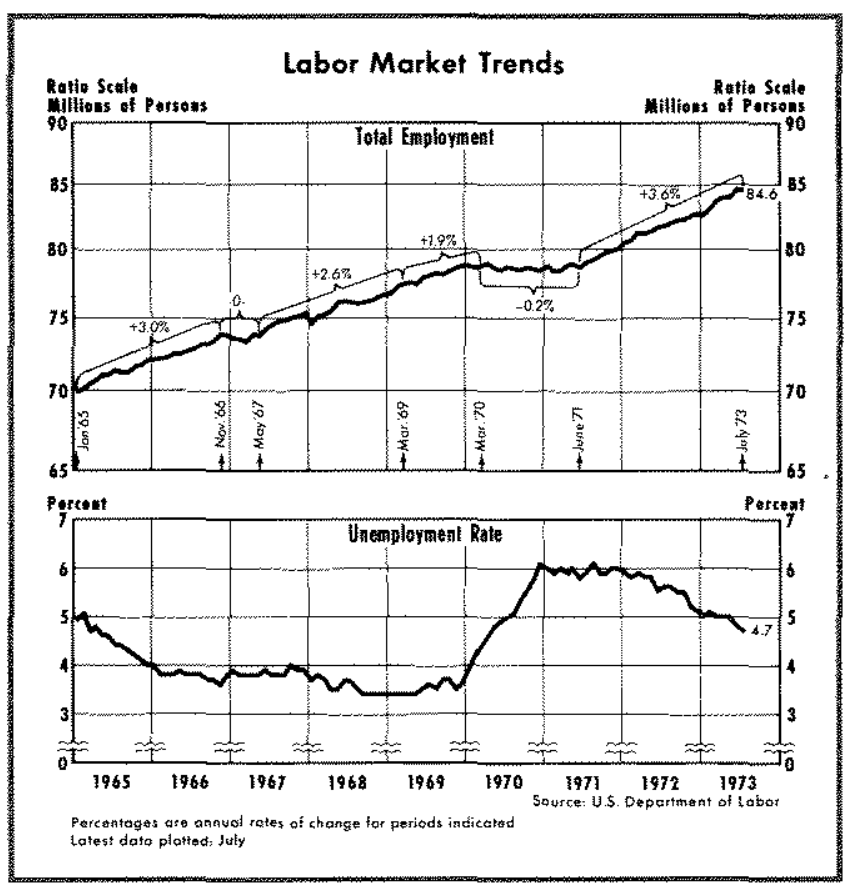

Given recent employment gains, the failure of the unemployment rate to drop much lower is explained by the rapid growth of the labor force. In the first seven months of 1973, the civilian labor force expanded at a 3.1 percent annual rate, compared with a 1957-72 trend rate of 1.7 percent. Total civilian employment as a percentage of the civilian noninstitutional population of working force age was at an historically high 64.8 percent in second quarter 1973 , a figure equalled in only one quarter in the past twenty-five years (fourth quarter 1969).

Sectoral Activity - The allocation of total spending among the various GNP sectors is governed primarily

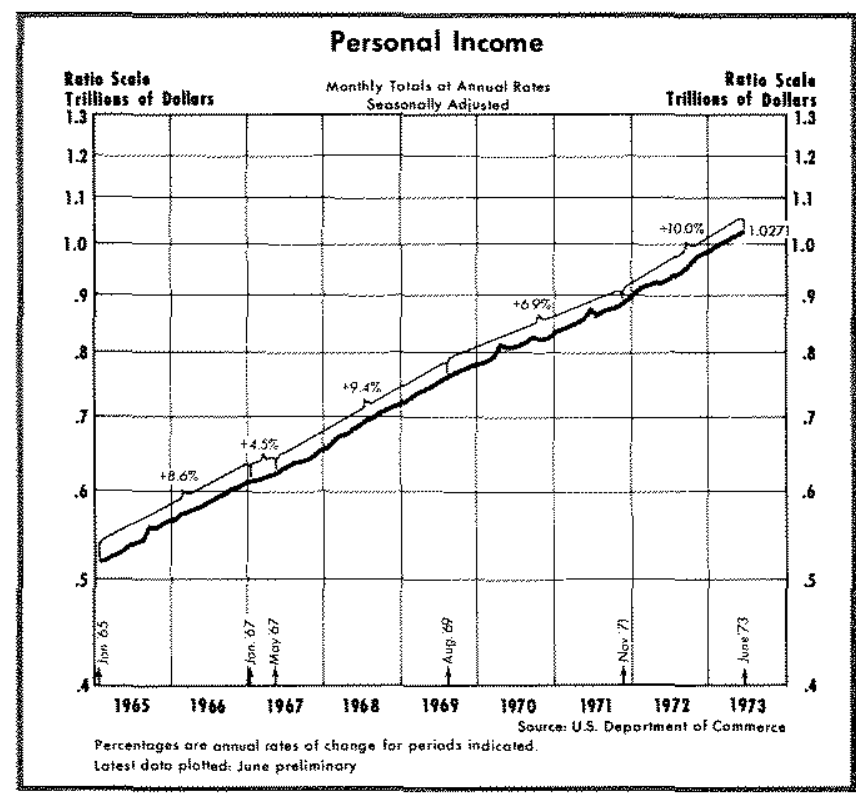

by market forces. Nonmarket constraints, such as interest rate ceilings and price controls, also influence the allocation of such spending.

Personal consumption expenditures rose at an 8.3 percent annual rate in the second quarter of 1973 , after rising at a 15 percent rate in the first quarter and by 10 percent in 1972. Purchases of durable goods expanded sharply in the first quarter, reflecting increases in expenditures for automobiles, furniture, and appliances. Expenditures for both durable and nondurable goods grew less rapidly in the second quarter.

Gross private domestic investment increased at a 10.6 percent annual rate in the first half of 1973 , after rising at a 15 percent rate since early 1971. Investment growth in nonresidential structures has accelerated, while investment in residential structures has decelerated from its earlier rapid growth rate. Investment in producers durable equipment has grown at about a 15 percent average amnual rate since the end of the $1969-70$ recession.

Investment in residential structures has increased each quarter for the past three years, but the growth in these expenditures has decelerated. Residential investment increased 41 percent from second quarter 1970 to second quarter 1971, 27 percent in the next four quarters, at a 16 percent rate in the second half of 1972 , and at a 9.3 percent rate in the first half of 1973.

Investment in nonresidential structures has followed a pattern opposite to that of residential structures and has accelerated since the $1969-70$ recession. Invest- 
ment in nonresidential structures rose at an 8.8 percent rate from first quarter 1971 to fourth quarter 1971, advanced 15 percent in 1972, and increased at a 17 percent rate in the first half of 1973 .

Book value of business inventories of firms engaged in manufacturing and trade has increased at a $\$ 21$ billion annual rate in the first five months of 1973, after rising $\$ 10.5$ billion in the year ended December 1972 and $\$ 8.7$ billion in 1971 . The inventory-to-sales ratio remained nearly unchanged from March to May 1973, after falling sharply from its peak level in 1970.

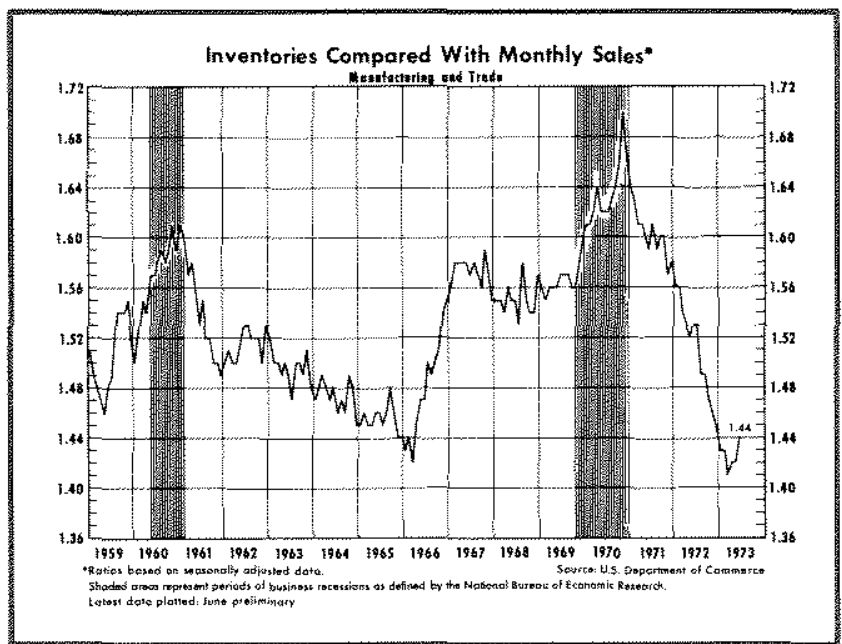

Retail sales growth, which was exceptionally strong in the first quarter of 1973 , moderated in the second quarter. Estimated sales in June, however, were still 12 percent above the year-earlier level. From 1957 to 1972 , retail sales grew at an annual rate of 5.5 percent.

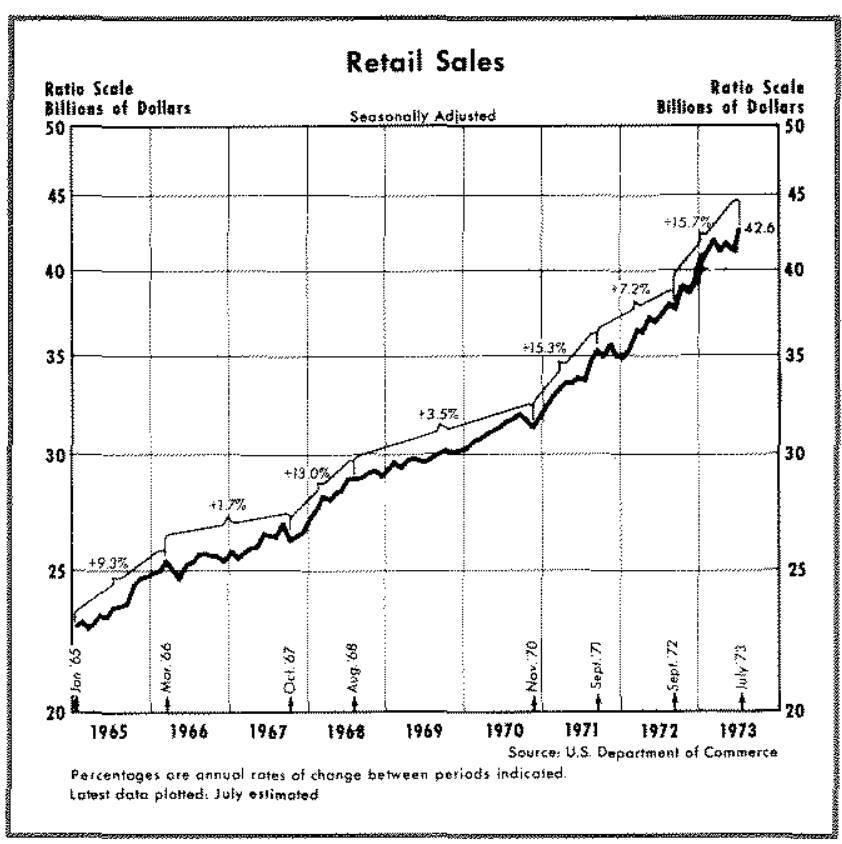

Inflation - Prices, as measured by all major price indexes, rose rapidly in the first half of 1973 . In response to the rapid price rise, the Administration initiated a 60 -day price freeze on June $13 .^{1}$ Because of developing shortages and distortions in the market, prices of most agricultural products and health services were exempted from the freeze in mid-July. ${ }^{2}$ For other industries the freeze ended on August 12 and was replaced by Phase IV controls, which bear some similarities with Phase II. Phase IV is intended to re" strain price advances primarily by allowing firms to raise prices only by the same dollar amount that costs have increased.

Both the GNP price deflator and the consumer price index indicate an accelerating rate of inflation in the first six months of the year. The GNP price deflator rose at a 6.8 percent annual rate in the second quarter of the year, after rising at a 6 percent rate in the first quarter and by 3.3 percent in 1972 . Consumer

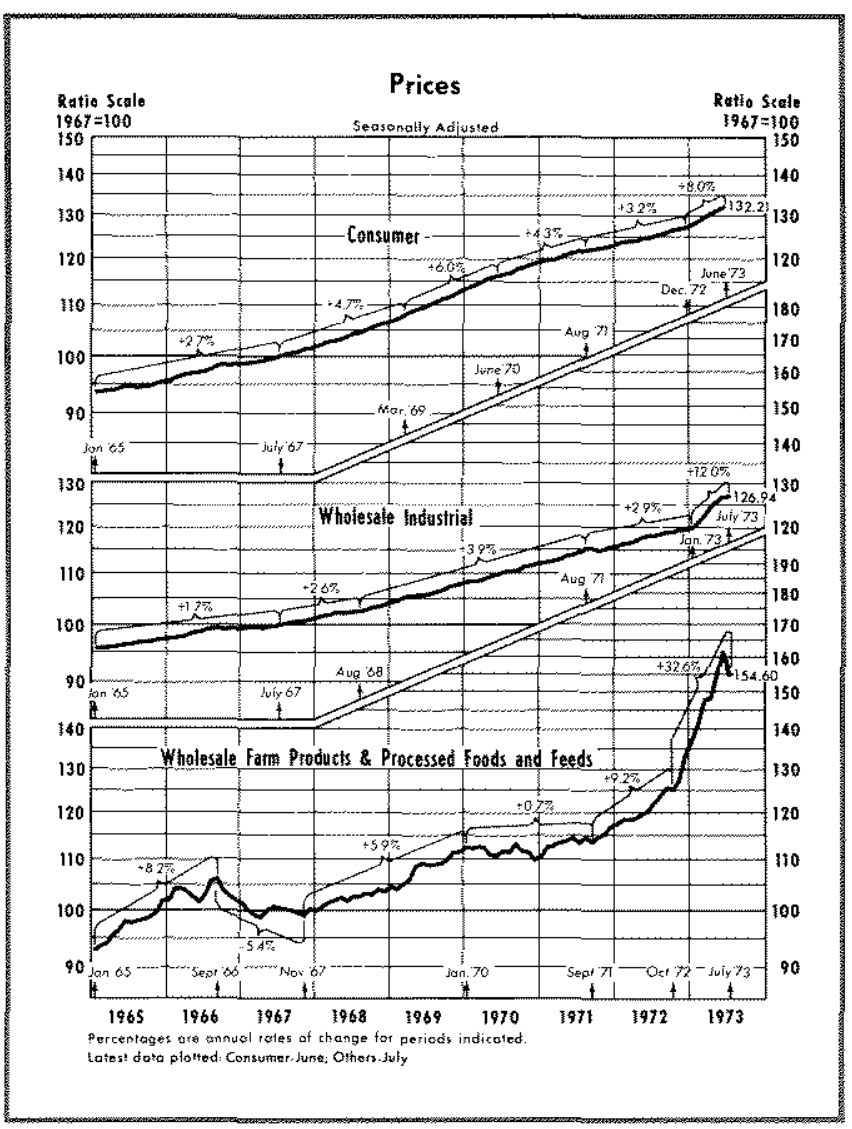

Unprocessed agricultural products at the point of first sale were excluded from the price freeze, while agricultural products at later stages of distribution were included in the freeze.

2The exemption permits prices of agricultural products, except beef, to rise by the same dollar amount that raw material costs have risen since early June. Beef prices at the retail level are to remain under the freeze until September 12, 1973. 
prices increased at a rapid 8 percent annual rate in the six months ending in June. For comparison, consumer prices rose 3.4 percent in 1972 and at a 4.9 percent rate from 1967 to 1971 .

The rise in wholesale prices of all commodities is up significantly from last October. Wholesale prices increased at a rapid 20 percent annual rate from October 1972 to June 1973 and declined at a 15.5 percent rate in the freeze-dominated period from June to July. For comparison, wholesale prices rose 4.9 percent in the previous year and at a 3.3 percent rate from 1967 to 1971 .

The wholesale price index consists of wholesale prices of farm products and processed foods and feeds and wholesale prices of industrial commodities. The rapid rise in average wholesale prices reflects the large and accelerating increases in the price of wholesale farm products which began in late 1971 and an acceleration in the rate of increase of wholesale industrial commodity prices since January 1973. Wholesale prices of farm products and processed foods and feeds, which carry a weight of nearly 29 percent in the wholesale price index, rose at a 9.2 percent rate from September 1971 to October 1972 and accelerated to a 47.4 percent rate from October to June 1973. Wholesale prices of industrial commodities rose at a 3.5 percent annual rate during Phase II of the New Economic Program, and increased at about a 14 percent rate from January to June.

The spurt in prices in the first half of this year is attributable to a number of factors. Some prices probably rose as a "catch-up" following the termination of Phase $I I$ or in response to anticipation of an eventual re-imposition of rigid controls. Prices of many agricultural commodities were affected by bad weather conditions and the strength of international demand. Capacity constraints reached in many industries in recent months have resulted in intensified price pressures throughout the economy. But the underlying cause of the current inflationary conditions is the excessive growth in aggregate demand relative to production capabilities. The rapid rise in aggregate demand, in turn, was fostered in large measure by expansive stabilization actions since 1969 .

\section{Stablization Actions}

During 1970, 1971, and 1972, both monetary and fiscal actions encouraged expansion in economic activity. On balance, monetary developments were stimulative in the first half of 1973 , while fiscal actions became less expansive.

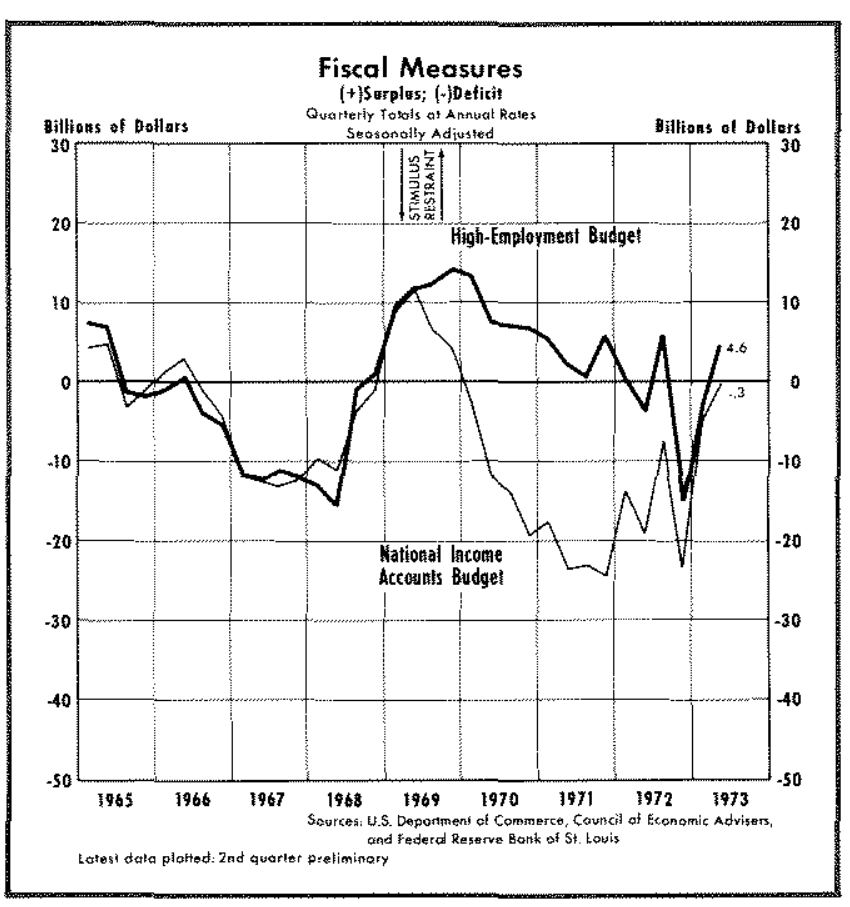

Fiscal Developments - The national income accounts budget moved from an average deficit of about $\$ 19.7$ billion in fiscal years 1971 and 1972 to a $\$ 9$ billion deficit in the fiscal year ending June 1973. A near-balance budget is projected for fiscal 1974. The smaller deficit in fiscal year 1973 reflects both a rise in receipts, due mainly to increased social security taxes and large increases in corporate and personal income, and a slowing in the growth rate of expenditures in the second half of fiscal 1973.

Growth of Federal Government expenditures slowed to a 1.3 percent annual rate in the first two quarters of 1973 after rising at a 13.4 percent rate in the previous two quarters. During the fiscal year ending second quarter 1973, Federal Government expenditures, which include purchases of goods and services, transfer payments, and grants-in-aid to state and local governments, rose 7.2 percent, compared to a 10.5 percent increase in fiscal 1972. National defense expenditures, which comprised 31 percent of Federal Government expenditures in fiscal 1973, fell 2.7 percent in fiscal 1973. Reflecting primarily a 17 percent increase in transfer payments and a 6.6 percent increase in grants-in-aid to state and local governments, nondefense expenditures rose 11.7 percent.

Financial Developments - The growth of the money stock $\left(\mathrm{M}_{1}\right)$, defined to include private demand deposits and currency in the hands of the nonbank public, has increased recently at a rate higher than its trend from 1967 to 1972 . The money stock rose at a 7.1 percent rate from November 1972 to 


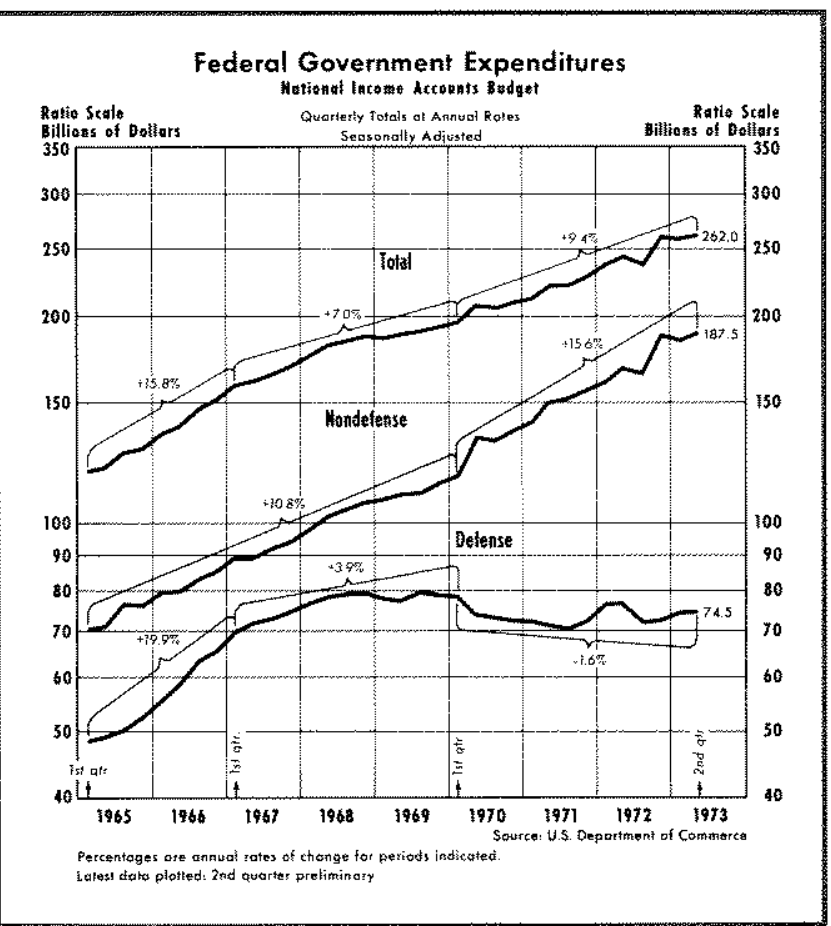

July. ${ }^{3}$ For comparison, the money stock grew at a 6.3 percent annual rate from 1967 to 1972 and at a 2.9 percent rate from 1957 to 1967.

In recent months the money stock plus net time deposits $\left(\mathrm{M}_{2}\right)$ also has grown at a rate higher than its 1967 to 1972 trend. $M_{2}$ has grown at a 9.1 percent rate in the three months ending July and has increased by 9 percent in the year ending April, compared to a 1967.72 trend rate of 8.4 percent.

The monetary base, a prime determinant of the trend growth of money, rose at a rapid 8.4 percent rate from November 1972 to July, about the same as the increase in the preceding year. Because of a temporary fall in the "money multiplier" in the first few months of 1973 and a subsequent rise in the ensuing months, money growth deviated from the trend established by the monetary base." From November 1972 to April of this year, the money supply grew at a

3The choice of the November base period attempts to avoid distortions which would be introduced into the rates of change calculations if December 1972 or January 1973 were used as the base period. The money stock rose at an abnormally high 14.1 percent annual rate from November to December 1972 and declined at a 0.5 percent rate from December to January.

4The money stock ( $M$ ) can be expressed as a function of the monetary base (B) and a money multiplier (m) such that $M=m B$. The money multiplier summarizes the decisions of commercial banks to hold excess reserves, of the Governtment to hold demand deposits, and of the public to hold demand deposits, currency, and time deposits. A discussion of factors affecting the money multiplier is presented by Jerry $L$. Jordan, "Elements of Money Stock Determination," this Review (Octoher 1969), pp. 10-19.

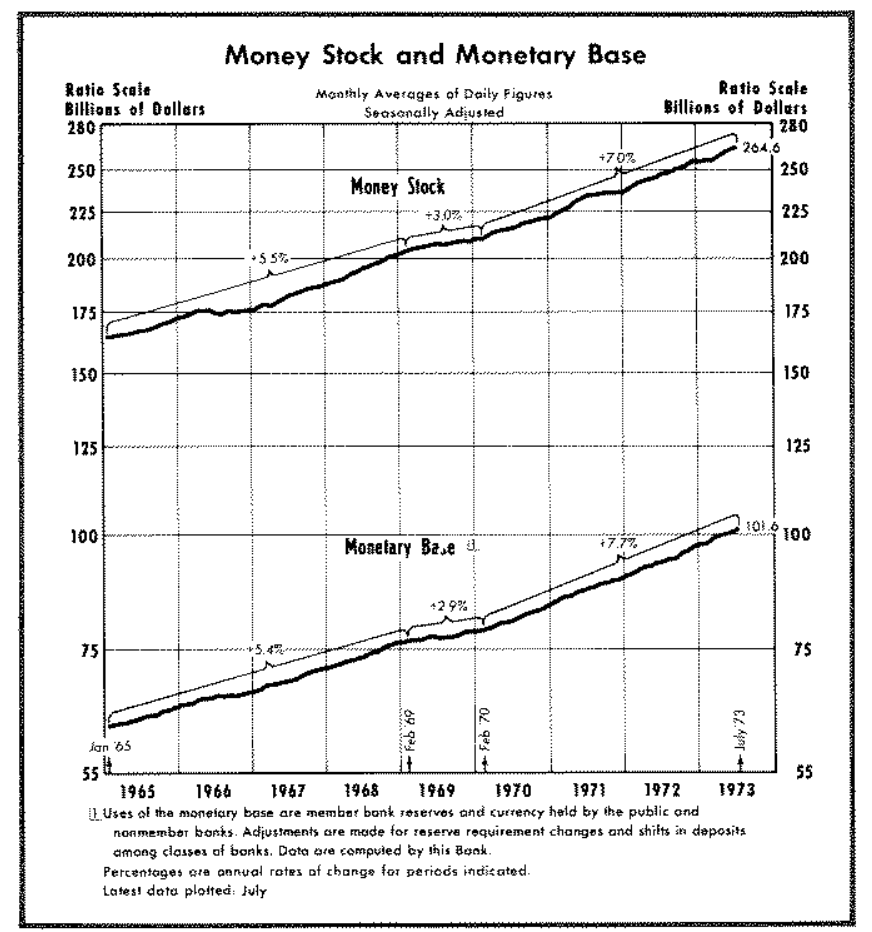

rate slower than the base, and from April to July the money supply rose at a more rapid rate. For the whole period, the growth of money was at about the same rate as that of the base.

Short-term market interest rates have risen rapidly in recent months, following the upward trend which began in early 1972, while long-term yields have increased moderately. Yields on three-month Treasury bills averaged 8.5 percent in early August, up about 1.5 percentage points from two months earlier. Reflecting the rapid increase in short-term market yields, the prime rate on bank loans was raised from $7^{1 / 4}$ percent at the beginning of June to $9^{1 / 4}$ percent in mid-August. The long-term Aaa corporate bond rate averaged 7.6 percent in early August, compared with a recent low of 7.08 percent last December and a 7.21 percent average for 1972 .

In response to rising money market yields, the Federal Reserve Banks have raised the discount rates

The decline in the money multiplier in early 1973 resulted from a more rapid growth of currency, time deposits, and U.S. Government deposits relative to private demand deposits at commercial banks. From November 1972 to April, currency grew at an 11 percent annual rate, total time deposits rose at a 23.5 percent rate, and demand deposits rose at a 3.7 percent rate. Treasury deposits at commercial banks averaged $\$ 6.2$ billion in November and rose to an average level of $\$ 10.1$ billion in March.

From Aprit to July, the multiplier rose towards its previous level. In this time period, demand deposits rose at an 11.7 percent rate, currency increased at a 4.9 percent rate and total time deposits grew at a 13.9 percent rate. Treasury deposits at commercial banks averaged $\$ 6.4$ billion in July. 


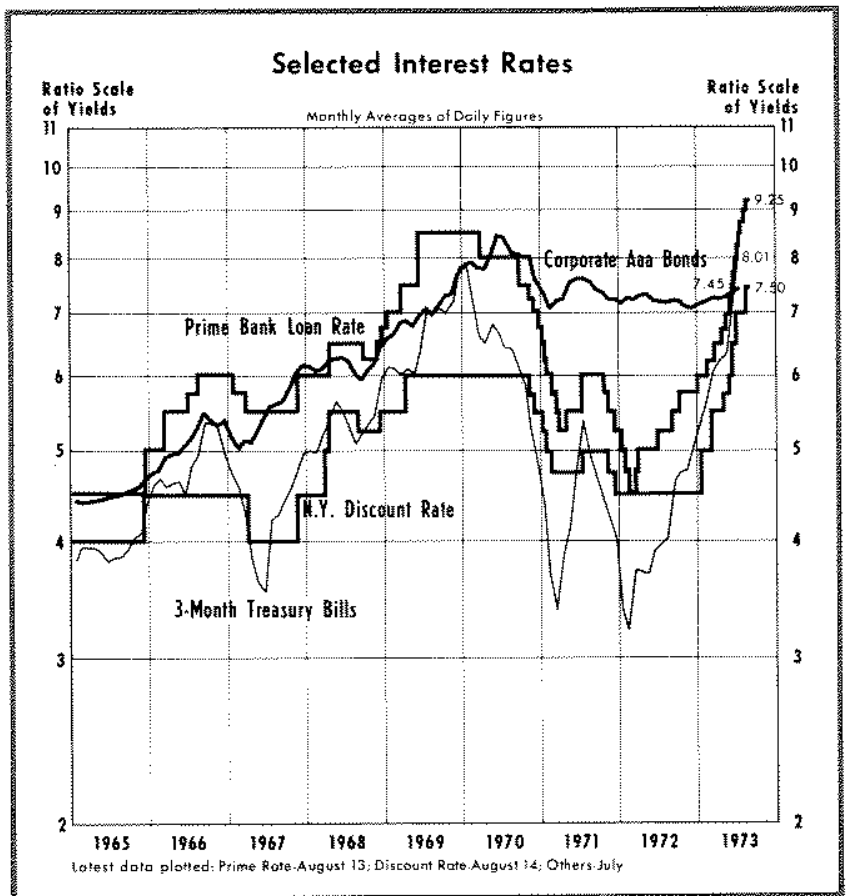

several times since December. At the start of the year, the discount rate was $4 \frac{112}{2}$ percent. It was raised by $1 / 2$ and $1 / 4$ percentage point increments to a $71 / 2$ percent level in mid-August.

In addition to discount rate increases, the Federal Reserve has made several changes in Regulation $Q$ interest rate ceilings and Regulation $D$ reserve requirements on member bank deposits. Regulation $Q$ interest rate ceilings on time deposits were changed in May, and interest rate ceilings on savings deposits were changed in July. ${ }^{5}$ Regulation $\mathrm{D}$ reserve requirement increases were announced in May, Jume, and

In mid-May 1973, the Federal Reserve suspended interest rate ceilings on certificates of deposit (CDs) of $\$ 100,000$ or more that mature in 90 days or more. Interest rate ceilings on CDs of $\$ 100,000$ or more with maturities of $30-89$ days have been suspended since june 1970. In early July, the Federal Reserve increased the maximum interest rate payable on passbook savings deposits at member hanks by $1 / 2$ of a percentage point. At the same time, maximum interest rates payable on consumer-type time deposits were increased by $1 / 4$ to $3 / 4$ of a percentage point. Interest rate ceilings were suspended on CDs of $\$ 1,000$ or more with maturities of four years or more. In late July, the Federal Reserve limited
July "However, the continued rapid expansion of the monetary base this year has fostered continued rapid money supply growth despite the restraining effects of other System actions.

\section{SUMNAYY}

Total spending increased at a rapid pace in the first two quarters of 1973. The growth of expenditures for consumer goods and residential construction slowed in the first half of the year from the unusually rapid pace of 1972, whereas the growth of nonresidential investment accelerated. Overall, growth of production and employment have recently decelerated toward longer-term trend rates as the economy has approached a high rate of resource utilization. Due to the constraint of available capacity, it is to be expected that the growth of real output would slow significantly from the rates prevailing in the period of recovery since the 1970 recession. As the growth of production slows further toward long-term potential rates, avoidance of further inflationary pressures requires moderation of the growth in aggregate demand.

the amount of "no ceiling" consumer-type CDs that a bank may issue to 5 percent of its total time and savings deposits. Those CDs that a bank sells beyond this amount will be subject to the existing interest rate ceiling of 6.5 percent that applies to time deposits maturing in $2 / 2$ years or more. The FDIC made similar changes affecting interest rate regulations on savings deposits at other commercial banks and mutual savings banks, and the Federal Home Loan Bank Board initiated changes affecting savings and loan associations.

GIn mid-May, the Federal Reserve increased reserve requirements from 5 to 8 percent on increases in the total volume of large time deposits and bank related commercial paper above the level existing during the week ending May 16 , or $\$ 10$ million, whichever is larger. At the same time, the Federal Reserve reduced from 20 percent to 8 percent, the reserve requirements on certain foreign borrowings of U.S. banks, primarily Euro-dollars. The Board also acted to eliminate gradually the reserve-free bases still held by some banks subject to this measure. In late June, the Federal Reserve announced that funds raised by member banks through the sale of finance bills would be included in the total voltme of large time deposits and bank-related commercial paper. previously, there were no reserve requirements on finance bills. In early July, the Federal Reserve raised reserve requirements on demand deposits at member banks. Reserve requirements were increased by $1 / 2$ percentage point on net demand deposits which exceed $\$ 2$ million.

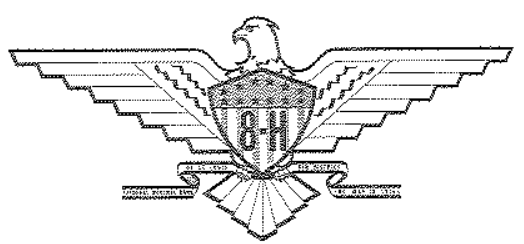

